\title{
SERBIA IN EU AND WTO NEGOTIATIONS
}

\section{SERBIA ON THE ROAD TO THE EU}

EU accession is Serbia's most important strategic goal. Serbia's negotiations to join the European Union are very complex and demanding. Serbia was granted EU candidate status on March 1, 2012. In September 2013, a Stabilization and Association Agreement between the EU and Serbia entered into force. On January 21, 2014, the first intergovernmental conference took place, signaling the formal start of Serbia's accession negotiations (1). The first chapters were opened in December 2015. After six years of negotiations, Serbia opened 18 thematic chapters (out of 35) from the EU acquis communautaire in Serbia's accession negotiations with the European Union and closed two chapters in 11 intergovernmental conferences. Serbia handed over additional negotiating positions in a further five chapters. Negotiating positions for the two chapters have not yet been handed over, and Serbia has yet to meet the initial benchmarks in the eight negotiating chapters. It also needs to meet the provisional criteria for Chapters 23 and 24. Only two chapters were opened in 2019 , and none in 2020, which represent the weakest result in this field since the end of 2015, when the first two chapters were opened (in 2016 four chapters were opened, in 2017 six, and 2018 again four). Chapters that have been opened within the framework of the accession negotiations by December 2020 are: 4 - Free movement of capital; 5 - Public procurement; 6 - Company law; 7 - Intellectual Property law; 9 - Financial services; 13 - Fisheries; 17 - Economic and monetary policy; 18 - statistics; 20 - Enterprise and industrial policy; 23 - Judiciary and fundamental rights; 24 - Justice, freedom, security; 25 - Science and research; 26 - Education and culture; 29 - Customs union; 30 - External relations; 32 - Financial control; 33 - Financial and budgetary provisions; 35 - Normalization of relations between Serbia and Koso-

\section{SUMMARY}

Key words: Serbia, EU, WTO, negotiations, trade

This paper deals with the Republic of Serbia's accession to the World Trade Organization (WTO) and the European Union (EU). Research is based on a literature review, understanding of current settings in accession, and synthesis of findings. Within the scope of the paper, there was presented genesis of both accession processes and current challenges. Results show that the Republic of Serbia has both interconnected and interdependent negotiations with the EU and WTO, which should be considered for further accession steps as we present within this paper. 
vo. Two of them have been provisionally closed (chapters 25 and 26). Serbia tabled its negotiating positions on chapters 2 and 21. Serbia was also invited to table its negotiating positions on chapters $3,10,14,27$, and 28 . So, after six years, we can say that Serbia has yet to reach the middle of negotiations. Essential chapters are considered to be Chapters 23 and 24, which relate to the rule of law, and the lack of progress in these Chapters can slow down the whole accession process.

For citizens of Serbia, visa-free traveling to the Schengen Area has been in force since December 2009. A readmission agreement between the European Union and Serbia has been in force since 2008. Serbia's fiscal adjustments in recent years have significantly improved the sustainability of public debt. The stability of the financial sector has been preserved, and the performance of the labor market has been enhanced except for the declining activity rate of young people. Serbia's foreign policy is in line with the EU policy of 53\%, which translates into 46 of 87 European declarations in the field. Major structural reforms of public administration and tax administration have progressed slowly. The state still has a substantial stake in the economy, and the private sector remains underdeveloped. There are weaknesses in the rule of law and the enforcement of competition. Investments have increased but are still insufficient. European Commission recommendation to Serbia regarding trade negotiations focuses on completing accession to the WTO by adopting an amended law on genetically modified organisms and completing remaining bilateral market access negotiations (2).

In 2018, the coverage of imports by exports of commodities in Serbia amounted to $74.2 \%$. Compared to the pre-crisis period, the share of export to GDP doubled, and in 2018 it amounted to $50.9 \%$ of GDP (see Table 1). Germany, Italy, and the Russian Federation are the largest of Serbia's external trading partners. Regarding China abovementioned, Serbia has a huge trade deficit.

Table 1. Serbia's Economic Indicators, in \% (3) Source: NBS - National Bank of Serbia

\begin{tabular}{lrrrrrrrrrrrr}
\hline & 2008 & 2009 & 2010 & 2011 & 2012 & 2013 & 2014 & 2015 & 2016 & 2017 & 2018 & 2019 \\
\hline Real GDP, y-o-y \% & 5.7 & -2.7 & 0.7 & 2.0 & -0.7 & 2.9 & -1.6 & 1.8 & 3.3 & 2.0 & 4.4 & 4.2 \\
Exports, in \% & 12.6 & -11.5 & 16.9 & 5.6 & 2.9 & 18.0 & 4.3 & 9.4 & 11.9 & 8.2 & 8.3 & 9.9 \\
Imports, in \% & 10.1 & -21.9 & -0.1 & 7.2 & -0.6 & 6.5 & 5.1 & 4.0 & 6.7 & 11.1 & 11.6 & 10.7 \\
NBS Key Policy Rate, in \% & 17.8 & 9.5 & 11.5 & 9.8 & 11.3 & 9.5 & 8.0 & 4.5 & 4.0 & 3.5 & 3.0 & 2.25 \\
Nominal Wages, in \% & 18.0 & 9.0 & 7.6 & 11.2 & 9.0 & 6.2 & 1.4 & -0.2 & 3.7 & 3.9 & 6.5 & 10.6 \\
Unemployment Rate, in \% & 13.6 & 16.1 & 19.2 & 23.0 & 23.9 & 22.1 & 19.2 & 17.7 & 15.3 & 13.5 & 12.7 & 10.4 \\
Current Account & & & & & & & & & & & \\
Deficit BPM-6 (\% of GDP) & 20.0 & 6.3 & 6.5 & 10.3 & 10.9 & 5.8 & 5.6 & 3.5 & 2.9 & 5.2 & 4.8 & 6.9 \\
\hline
\end{tabular}

According to the European Commission 2019 Report for Serbia, the country has continued to perform well in meeting its obligations under the Stabilization and Association Agre- 
ement. In 2018 some restrictions on the possibility to grant loans to non-resident borrowers were lifted, and Serbia also removed the export ban on non-hazardous waste, which restored free trade. Serbia continues to participate in the multilateral economic dialogue with the Commission and EU Member States to prepare for participation in multilateral surveillance and EU economic policy coordination. As part of the new approach to economic governance, Serbia adopted its fifth economic reform program and is implementing reforms recommended by the Economic and Financial Affairs Council. Improvements are needed in the area of the capacity for economic planning, inter-ministerial coordination, and implementation. Also, compliance issues remain in state aid and fiscal discrimination on alcohol, and restrictions on the acquisition of real estate also remain. In June 2018, Serbia introduced new restricting rules regarding the issuance of payment cards by banks - that are not in line with the EU acquis and the Stabilization and Association Agreement.

Serbia, as a candidate country negotiating the EU membership regarding public procurement, inter-governmental agreements concluded with third countries, and their implementation should follow the EU principles of equal treatment, transparency, non-discrimination, and competition. Non-compliance with the principle of equal treatment, transparency, non-discrimination, and competition, according to the mentioned European Commission Report, has the effect of preventing EU companies from participating in large-scale infrastructure projects implemented in the country.

The Republic of Serbia, which has been in the EU accession process for a long time now, is now turning to China as an economic partner and the EU as a major economic partner. Trade between China and Serbia tripled between 2005 and 2016, to 1.6 billion USD, but it is a very unbalanced relationship: China exports approximately 1 billion USD in goods, whereas Serbia exports 1 million USD of goods to China. Investments are rising because the Serbian government can act quickly as a non-EU member. We will see how things will go in the future, but there are positive developments in this economic cooperation.

Johannes Hahn, European Commissioner for European Neighborhood Policy and Enlargement Negotiations, expressed concern that some Balkan countries were borrowing heavily from China. If a government cannot pay its loans, there is some pressure for transfer into Chinese ownership. He pointed out that the EU is maybe slower and demands more than the others, but in the end, they are by far the fairest partner (4). Although the EU holds the largest investor in Serbia, growing Chinese investment has not gone unnoticed and unresponsi- 
ve. Regarding Serbia, the European Union is already concerned over Russian influence, especially in media and culture.

On the other hand, for the EU, China poses a much more dangerous threat because its influence is growing not only in the culture and media but also in the economic area. Concerns about Chinese investments were also raised in a 2017 report from the European Bank for Reconstruction and Development. China, as a country involved in Serbia, has the benefit of not having to abide by EU legal rules. Most Chinese enterprises that have entered the Serbian market are either state-owned or have close ties with the Chinese state. Chinese companies are also increasingly perceived as dangerous competition within the European Union.

Major structural reforms of state-owned enterprises in Serbia have progressed much slower than expected from the EU officials. The fact is that the European Union requirements under the negotiation process include those for the privatization of large state-owned enterprises in Serbia. That means that all companies owned by the Republic of Serbia, local

Major structural reforms of state-owned enterprises in Serbia have progressed much slower than expected from the EU officials. self-government, or the province are potential privatization candidates. In line with these recommendations, two important privatizations were completed: the steel mill Smederevo in 2016 and the mining company Bor in 2018. In both companies, the majority of owners became companies from China. Since there are still large state-owned companies in Serbia, they are potential candidates for privatization in the following years.

\section{SERBIA'S NEGOTIATIONS FOR WTO MEMBERSHIP}

Relations between the Federal People's Republic of Yugoslavia and the General Agreement on Customs and Trade (GATT) began from the observation stage, which lasted from 1950 to 1958. With the signing of the Declaration on the Regulation of Relations between Yugoslavia and GATT on May 25, 1959, relations moved on to the stage of associate membership. On August 25, 1966, SFR Yugoslavia fully acceded GATT. At the initiative of the European Community on June 16, 1993, a Decision was adopted which definitively challenged the FR of Yugoslavia (Serbia and Montenegro) to "automatically continue" the former SFRY's membership in the GATT, thus effectively excluding the FRY from the GATT (5). Negotiations on Serbia's accession to the World Trade Organization began on February 15, 2005. After the Working Group is established, negotiations for admission to the WTO begin. Negotiations are conducted according to a pre-established WTO procedure. The procedure includes two types of negotiations:

- negotiations on rules, which are multilateral and conducted based on the Memorandum on Foreign Trade Regime; 
- market access negotiations, which are bilateral and conducted based on concession proposals.

The length of negotiations depends on the Working Group's number of meetings necessary to reach an agreement. Serbia's working group met a total of 13 times, the last time on June 13, 2013. The next meeting of this working group is expected when Serbia completes the procedure of adopting the remaining legal solutions in accordance with WTO rules (primarily regarding the trade of GMO products), when the work on the new draft report of the Working Group is completed and when significant progress is made in the remaining bilateral negotiations on market access (i.e., when a new bilateral protocol on access to the goods and services market is signed) (6). Unfortunately, from 2013-2020, Serbia did not achieve any significant progress that would lead to holding a Working Group meeting.

Because Serbia wants to join the EU, it must consider the interests of the EU during negotiations with the WTO. Serbia must take care of balancing the negotiating positions. Simultaneously, Serbia's accession to the European Union, which has a unified foreign trade policy, significantly affects the room for maneuver of the negotiating team for accession to the WTO. The European Union recommends that Serbia does not lower customs duties below the level of consolidated EU customs rates during the bilateral negotiations in joining the WTO. The European Union does not want Serbia to make Estonia's mistake in entering the WTO when it reduced specific customs duties to a level lower than the one that existed in the EU. Thus, this community was forced to pay compensation after the accession of Estonia duties to third countries. That is why the EU demands Serbia to persevere in the negotiations and consolidate its customs duties at a level that is at least the same, if not higher, than the one in the EU (7).

\section{INTERCONNECTED AND INTERDEPENDENT NEGOTIATIONS WITH THE EU AND WTO}

Due to the importance that the EU attaches to Serbia's negotiations with the WTO, the European Commission closely monitors them and provides comments and recommendations in its annual reports. WTO membership remains dependent on the adoption of a law on genetically modified organisms in accordance with WTO rules and on the completion of market access negotiations with

Serbia should ensure the compatibility of its bilateral investment agreements with the EU Acquis communautaire. several WTO members. It was also stressed that Serbia should ensure the compatibility of its bilateral investment agreements with the EU Acquis communautaire.

As mentioned, Chapter 30 - External relations, opened on March 30, 2015, has been opened within the accession negotiati- 
ons framework. The most critical unfinished task in this chapter is negotiations for WTO membership. So, the necessary condition for closing this chapter is Serbia's accession to the World Trade Organization. Uncertainty over the date of Serbia's WTO accession makes it challenging to prepare plans to meet European standards in negotiations with the EU.

In addition to Chapter 30, the fact that the WTO accession negotiations have not been completed also makes it difficult to prepare to negotiate positions defining deadlines and how to adapt to the EU in 29 - Customs union, because WTO and EU membership affects Serbian customs, as well as Chapter 11 Agriculture and rural development and Chapter 12 - Food safety, veterinary and phytosanitary policy.

Therefore, we can see that the WTO's accession is a fundamental issue for Serbia and significantly affects

The WTO's accession is a fundamental issue for Serbia and significantly affects

the content and speed of negotiations with the European Union. the content and speed of negotiations with the European Union. The possibility for Serbia to join the WTO just before the end of negotiations for EU accession is also not sustainable because Serbia's foreign trade policy after WTO accession, in addition to this organization, will be closely monitored by the European Union to decide whether Serbia is ready to join the common trade policy union (8).

\section{CONCLUSION}

As mentioned in this paper, EU accession represents the Republic of Serbia's most important strategic goal. Serbia's negotiations to join the European Union are very complex and demanding. Serbia was granted EU candidate status on March 1, 2012. Until this moment, the Republic of Serbia opened 18 thematic chapters out of 35. One of the recommendations for the Republic of Serbia provided by the European Union was also to complete accession to the World Trade Organization. The interconnection and interdependence between Serbia's negotiations with the EU and WTO make our country reduce the room for maneuver to get the best possible position in both negotiations. Negotiations between Serbia and WTO for accession started back in 2005, and working groups met 13 times. The last visit was in 2013, and since then, there is no progress on accession to the WTO.

In addition to the EU as a major economic partner in recent years, Serbia is also turning to China as an economic and strategic partner. The fact that Serbia has not yet become a full member of the EU has, in a way, enabled certain investments from China. However, those investments are not balanced and favor China in terms of trade balance (i.e., China exports approxima- 
tely 1 billion USD in goods, whereas Serbia exports 1 million USD of goods to China). Several European Union officials have sent warnings about China's growing influence in Serbia. Serbia's accession to the European Union, which has a unified foreign trade policy, significantly affects the negotiating strategy for accession to the WTO.

On the other hand, European Commission 2019 Report assessed Serbia as a performer, particularly in meeting the Stabilization and Association Agreement. Also, Serbia should deal with the rest of (large number) state-owned enterprises in the future.

Having this said, the Republic of Serbia has numerous challenges in further accession to the EU and WTO. Therefo$\mathrm{re}$, as there is an excellent benefit for the country to become a member state in both WTO and EU (prospectively), further efforts should be made in this direction. Interconnectivity and interdependence of accessing the Republic of Serbia to both the EU and WTO are present largely. They should be considered for further steps in accession, as we are presenting within this paper.

\section{LITERATURE}

1. Sanja Jelisavac Trošić. (2018). "Serbia's Sustainable Development Strategy and Industrial Policy for the European Union and the World Trade Organization", in: M Yülek (ed.), Industrial Policy and Sustainable Growth, Springer, Singapore

2. European Commission. (2020). Serbia 2020 Report, SWD 352 final, Brussels. Available at https://ec.europa.eu/neighbourhood-enlargement/sites/near/files/serbia_report_2020.pdf, Accessed on: $6 / 10 / 2020$

3. NBS. (2020). Serbia's Economic Indicators National Bank of Serbia. Available at: https://nbs.rs/sr/finansijsko_trziste/informacije-zainvestitore-i-analiticare/podaci/index.html, Accessed on: 6/10/2020

4. Rebecca Banovic. (2019). China and Serbia Sign Major Infrastructure Deal Under the Belt and Road Initiative, Forbes. Available at: https://www.forbes.com/sites/rebeccabanovic/2019/04/28/chinaand-serbia-sign-major-infrastructure-deal-under-the-belt-and-roadinitiative/\#1fffe0642dde, Accessed on: 23/05/2019

5. Jelisavac Trošić Sanja. (2015). Pregovori u okviru GATT i STO, Institut za međunarodnu politiku i privredu, Beograd, 2015

6. World Trade Organization. (2020). Annual Report by the DirectorGeneral WT/ACC/28. Geneva: WTO, 14.

7. Jelisavac Trošić, Sanja; Rapaić, Stevan. (2015). Stanje i perspektive pristupanja Srbije Svetskoj trgovinskoj organizaciji. Međunarodni problemi, 1/2015, Vol. LXVII, Beograd: Institut za međunarodnu politiku i privredu, 128-147, 132

8. Jelisavac Trošić Sanja, Todić Dragoljub, Stamenović Milorad (2018). Svetska trgovinska organizacija, životna sredina i sistem zdravstvene zaštite. Institut za međunarodnu politiku i privredu. Beograd

\section{SRBIJA U PREGOVORIMA SA EU I STO \\ REZIME \\ Ključne reči: Srbija, EU, STO, pregovori, trgovina}

Ovaj rad se bavi pristupanjem Republike Srbije Svetskoj trgovinskoj organizaciji (STO) i Evropskoj uniji (EU). Istraživanje se zasniva na pregledu literature, razumevanju trenutnih postavki u pristupu STO i EU kao i sintezi nalaza. U okviru rada predstavljena je geneza oba pristupna procesa kao i savremeni izazovi. Rezultati pokazuju da je Republika Srbija ima i međusobno povezane i međuzavisne pregovore sa EU i STO što bi trebalo razmotriti za dalje korake u pristupu kakve predstavljamo u ovom radu. 